\title{
Blasts to Nucleated Cells Ratio Measurement
}

National Cancer Institute

\section{Source}

National Cancer Institute. Blasts to Nucleated Cells Ratio Measurement. NCI Thesaurus. Code C147312.

The determination of the ratio of blasts compared to nucleated cells present in a sample. The measurement may be expressed as a ratio or percentage. 